\title{
RATIONALISM IN DANTE'S DIVINE COMMEDY AND ARDAVIRAF
}

\author{
Mohammadreza Shahbazi ${ }^{1}$, Maryam Jamali ${ }^{2}$ \\ ${ }^{1}$ Department of Dramatic Literature, Bushehr Branch, Islamic Azad University, Bushehr, Iran, \\ mrsh3072@yahoo.com \\ ${ }^{2}$ MA Student Department of Dramatic Literature, Bushehr Branch, Islamic Azad University, \\ Bushehr, Iran, sydartmary@gmail.com
}

\begin{abstract}
The main purpose of the paper is to study rationalism in Dante's Divine Comedy and Ardaviraf. Wisdom is like a textile, which consists of fibers called knowledge and sagacity. The duty of sages has been to transform these initial materials into practical products; On the other hand, wisdom is the reflexive of knowledge that we should use to reach upper level of humanity.

In this paper an attempt is made to use library based and descriptive research methodology; the results show that Iranian people are considered as rational people history. For example, Ahura Mazda in Zoroastrianism is the symbol of wisdom and he was considered as an honest man who was in favor of truth; he was the source of goodness.

On the other hand, Dante's Divine Comedy has taken a long step in breaking the spell that church had imposed on Dante's contemporary society; it is also the first step towards the new revival in the dark history of the middle ages. It is the beginning of the golden age of the Renaissance; it is also the beginning of rationality and humanism in the golden age of the European history.
\end{abstract}

Keywords: Wisdom, Divine Comedy, Ardaviraf

\section{INTRODUCTION}

Reasoning power distinguishes man from other animals. Wisdom always has high position human thought system and praise is to all races. The brightest vertex of humanity is the theme of real human life and cause access his perfection and education material and spiritual. Wisdom always with two features know and recognize; on one hand is cause different between good or bad and in the other words cause man prevents of the defection of right and it has provided toys health and happiness. Interrupt wisdom dominance not only personal life, but also it has made community life as well as the scanning and development and social relations have led to towards moderation. (Vejdani, 1391: 42)

There are many works in Persian literature that deal with culture, and in fact they reinforce Iranian culture that contains a long history of literature and a variety of works with different accents. The oldest work namely 
Zoroasterian Gathas and many recent works follow the creative spirit and bright ideas of the Iranian people. (Safa, 1378)

Book of Ardaviraf is one of the most beautiful religious texts that is left of the ancient Persia; as Mojtabamenui has pointed out in fifteen speech book, this book been as a source of great works like Dante's Divina Commedia and Sanaii'sSeyr-o-Ebad. (Menui, 1346:33)

ArdvayrfNamak or Book of Ardaviraf, is the name of one of the books written in Persian Pahlavi; that is a reminiscence of the magnificent kingdoms of Sassanids. The Holy Viraf is the name of one of the priests that accordingly has been the owner of the ascension andArdavirnamh is about him and his adventures.

The poem, Divina Commedia is one of Dante Alighieri's masterpieces (1321-1265). It is divided into three books, Book of Hell, Book of Heights and Book of Heaven. (Menui, 1346: 26) It has been the source of Tuscan accent and this provincial accent was considered as a general language in Italy. (Menui, 1346: 29) It is because of this poem that the readers are acquainted with art and religion in Europe, and it also created new literature and the period that Europeans consider renaissance; it has had great influence on the literature of the modern period. (Menui, 1346: 45)

Soon after Dante's death, this book turned into a classic in Italy. (Safa, 1378: 37) Dante's Divina Commedia is one of the excellent works of philosophical thought; it deals with thousands of years of human science, and philosophical theories and ideas which are mixed with a special combination. Divina Commedia is an allegory filled with lots of references and metaphors. (Alighieri, 1347, e. 1:40)

\section{REFLECTION OF WISDOM IN BOOK OF ARDAVIRAF}

Zoroastrian religion, survived for three hundred years, until Alexander, attacked Iran and burned the book of Zoroastrianism, that was written on cow skin; there had all Dadvaran, Hirbod and priests killed, and a religion hostility was initiated between men and gods' chief. It was then that the people of Iran were not aware of governor and in rituals, creed and conversion. It created differences and mistrust among the Iranians. It was then that Azar Badmr Espandan emerged at the time of Sassanid Shapur II (309-379), when people were in disbelief. The priests came together in Azaran Farnabagh to find a solution and they said that they should choose among themselves one person who would bring news of religious instructions to all of the people living in Frnbkh port. There were seven men who were incredulous to God and they adopted one of them called Vyraf.

After Ardaviraf takins a bath, he would wear clean clothes and there would have food; he would then choose thirty steps away from fire. He would sit on bed decorated, a new carpet, and after eating he would drink wine and bang Goshtasb, they give him three golden cup, a cup of good works, a cup of good idea , a cup of good deeds.

He was whispering prayer and would sleep and to religion commands and seven sisters would him to read Avesta. Viraf went to Damtykchkaty Mountain and Chinud Bridge, and he woke up Azar Ezad and Soroushguidanc with the passing of purgatory, and hell after seven days with wisdom and clear thinking, after that sisters and priests were very happy. Vyraf would bring for them greeting and goodness from Ahura Mazda and holy Zoroaster Aspytmanandsoroush is Azar Ezad, and other deities.

Religious commands also send greeting to Vyraf, and tell us what you see. They wanted to bring wise secretary that would be able to write what Vyraf said. (Yasmi,ND)

\subsection{Wisdom in Mazda Religion}

Ahura Mazda, meaning wise leader is the name given to God by Zoroastrians. As it is clear from his name, wisdom is his feature, someone who neither tricks nor being fooled. He is generous and absolute $\mathrm{r}$. He is the father of creation and mother too; he has made path of the sun, moon and stars. He was, is, and will be. In other words, he is immortal. (Hynlz, 1373: 69)

God is the source of all goodness: light, life, beauty and happiness, health. God is source of inspiration all the right and ground symbolize is pious man. (Hynlz, 1373:70)

Wisdom is most important in Mazda religion. Oormazd is the knowledge of cheerfulness that gives wisdom to people: (when you granted to us of your character in the started world you created religion). (Pourdavod, 1384: 464)

They create of paramount right mind :(Hurmazd policy and Mshyaneh said that I created you of right mind do task with right mind) (Dadgy, Frnabagh, 1381:81). Likewise, the origin of the human intellect is source of 
clean and refined. Refinement of wisdom and attendance with Goodness and right is the feature that is inseparable from Mazda texts; in a way, wisdom without goodness isn't considered wisdom). (Tafzili, 1385:33)

In Mazda teachings wisdom is divine characteristic. With the benefit of wisdom, it is human deeps and pleasant. Wisdom is defined as: (diagnose better from to worse and it better and to release worse. (Bozorgmehr, 1361: 484)

The title of the book in Pahlavi is "Artavirfanamak". (Moein, Mohamad, Purdavod Obituary, 1325:182-150). Some Orientalists like Barthelme, and vast following the Zoroastians tradition, it call it Ardaviraf and Ardaviraf. First word "Arta" is synonymous with asha in Avasta and "rta" in Sanskrit and it is called truth, right, holiness and purity. Second part as Vira, is special root in Avesta and in two states: 1-man 2-intelligence and wisdom, last part, "Af", is tool defined. Ardaviraf, is mean holy person or holder intelligence and wisdom and holy wisdom. (Erfanian, 1385: 47-56)

\subsection{Wisdom in Sasanid Era}

During the aristocratic Empire - Sassanid religious and the despite class pressure and in equality between people in Iran and Iranians love luxury, some scientific and technical, and art activities happened that they have done with support of the court. This effort included scientific activities in the field of astronomy, medicine, the drug andv translation of Sanskrit books and Greek was to Pahlavi language. (Ershad, 1383:148)

Ardavarafnameh brochure according to the content in the text belongs to Sassanid era and regulations. In the Pahlavi brochure introduction first chapter (Azar Mar Aspandan) it is tested before the heavenly travel (viraf), (var) is mentioned.

The priest, priest of Sassanid era and contemporary shaper II (309-379) was son of Hormuz. Considering this subject, we realize that vyraf life time, goes back prior to the end of the fourth century AD, likewise can't be later than 651AD - the last year Sassanid king, Yazdgard third, the beginning of introduction of Pahlavi brochure Ardavayrafnameh appeared: (the evil shrew (enemy, ugly and flooded) to alienate the people to religion (Zoroastrian), out Alexander damned predominantly Rom Egypt...). It is well known by author of the religious and political anarchy the result Alexander dominance and successor in Iran found and consider the sequence was drawn to the Parthian era. (Ershad, 1383)

\section{REFLECTION OF WISDOM IN DANTE'S DIVINA COMMEDIA}

Divina Commedia is a masterpiece of Italian literature, effect of Dante Alighiri. This work was written during the middle ages. At the beginning of the book, Dante is poet and the narrator halfway 35 years, wandering in the dark forest that suddenly, Virgil ancient Roman poet appeared and both of them traveled to other world.

Virgil, as a guide, Dante takes traveled to hell and limbo and heaven. This traveled was performed during 7 days, of April eighth night 1300A.D until April fifteenth 1300.

Dante and Virgil's first destination is hell. The most basic property hell is lack of hope. Dante and Virgil goes to limbo, the stage distance between sin and right.

They wash their regret and repentance with water and with force of hope, in the fall, the third namely paradise (A symbol of peace and salvation). Limbo is the place of those who sinful but they have well.

Virgil is with Dante half of the way, but from then on, because Virgil is sentenced to hell he can't accompany Dante.

Here Batrys is in his position on the ninth floor of paradise, namely top floor where people can go and he come help to Dante and he was along end of traveled. The final step is heaven that on the road impassable reach to high point heaven. In the end, Dante reaches the supreme throne and sees landscape light of God. Dante sees in heaven several of the elder and loved ones, they listened to the advice, and he wrote the story of their journey in memory, others learn of that story. Divina Commedia has 33 hymn that in addition to first hymn hell, in fact is introduction on God's comedy, totally have 100 hymns. Each hymn divided to three hemistich and includes different of 110 to 160 hemistich. (Alighieri, 1347)

\subsection{Virgil as a Symbol of Wisdom}

\subsubsection{Gilius old poet Rom}

Publish and giliusmaro are third classical poet and rural songs author (Gvrcake/ namely pastoral poems 
aftermost third epic poem of twelve book was national epic of Roman Empire. In Dante book and Virgil is symbol of common sense. (Menui, 1346)

\section{RENAISSANCE, A STEP TOWARD RATIONALITY EUROPEAN}

With the disappearance of Medieval era and the emergence of the Renaissance has close relationship with the fall of Feudalism, growing urbanization, power of princes, oppose the teaching and the principles of church life (Bracket,1383, e1:283) . maybe renaissance continuous more than anything with humanitarianism growth and revival of the classic style of world, if the name is, return human values and his biological life (Bracket,1383, e1:283) humanism weren't ungodly but weren't ascetic.

They were thinking the ideal way of life and with realistic insight. It is estimated that the human being which is appreciated and praised and prone to corruption. Humanism inspired the classical world where the humanism and regarding motivation across Europe were to Greece and Rome (Bracket, 1383, e1:283) by increasing his credibility of the person and facilities, anonymous medieval craftsman and writers were converted into artists with great personal achievement. Bible topics and birth certificate his place in classical mythology, history, and stories analyses.

Perhaps we can say that with Renaissance, art began in Italy about 1300 with Dante (1265-1321), Although Dante dealt with topic of religious birth, Virgil was chosen as it's guidance in Divina Commedia (Bracket,1383, e1:285)

\section{SIMRLARITIES BETWEEN THE RATIONALITY IN DANT'S DIVINA COMMEDIA AND BOOK OF ARDAVIRAFNAMA}

The most important evidence for the importance of Dante's Divina Commedia and Ardavirafnameh is an invitation it extends to people to neglect cleanliness and remove fate of the postal and impurity and revive forgotten religion.

At the end of their trip, Ardaviraf with SoroushAhlu and AzarEzad go to the endless light, and community Oormazd and Amshaspbandan.Oormazed said that go to the supernatural world, recounted what you see and know do good ideas, good words, good deeds and stand the same religion that I accept Zoroaster Spntman and was encouraged Goshtasp in the world..(Hejazi, 1390: 8-9)

In Divina Commedia that called as four famous epics, the world journey from the depths of hell to the highest level of heaven relying on two elements of fantasy and revelation, is unique for revival and strengthen Christianity and match facts on the realities of society.

The biggest of his art is at the height of darkness of the history of Italy, created symbolic effect and very strong, that it's prominent role intellectual public cannot be ignored of reality of reality bitter of his time and religious support.(Hejazi, :8-9)

In both works, Ardavirafnameh and Divina Commedia are grumbling and complain about sin and corruption of his time. Both of them are kept with tense atmosphere and full of corruption and people away from religion. (As history repeat)

Dante refers to Alexander and people with weakness in faith (Iran suffers from some kind of political chaos and political policy written by priests until was and steady the social, religious and political).

During the Florence Dante has been subject to political events and the dispersion of votes have been between political groups. This reflection is visible in hell and the grudge evil had in the heart. Both of them created for awareness of general and specific, and both of them have forms of aphorisms; however Divina Commedia has intellectual plans to remove corruption and debauchery of many famous people of his time. Both will be asked after returning tell the world have been seen and known. Ahuramazda said to virafKachia Guido (Dante great grandfather) and byars such sentences are to Dante.

In both work is taken into consideration good and evil and good and bad, theft, cruelty ( king of the countryside ), meanness, violating the privacy of other, in Ardavyraf, those who have money and land assault partner and have their.

In Divina Commedia (usurious and marauding), in Ardavyrafnameh to voodooism and in Divina Commedia to sorcey, prediction are mentioned likewise in Ardavyrafnameh is mentioned lying. In Divina Commedia is mentioned speak forgeries.

Shmuyan is in Ardavirafnameh and Zanadyg (magus) is in Divina Commedia. Also cited lazy (in hell) 
Ardavyrafnameh and complacent (in limbo) Divina Commedia woman who deceive people in Ardavyrafnameh and pirates honor in Dante hell at cunning part, new religion and those who are not Christian and baptism in Divina Commedia Except for the above also cited lust in Ardavyrafnameh the fifth chant sensuality in Dante hell second floor. Ribald is Ardavyrafnameh and the lord's wrath in eighth chant, in Dante hell fifth floor. Covenant breakers in Ardavyrafnameh are thirty-second to thirty fourth Dante hell. The man who challenge lies woman in the world and taking bribes, corrupt consultants in slays and bribery makers are DivinaCommedia those who are envious evil eye is in Ardavyrafnameh, and people envy in XIII and XIV chant in Dante hell. Misdeeds have suffered father and mother in Ardavyrafnameh and traitors to parents in the betrayer section in Arad Vyrafnameh in Dante's Divina Commedia. In both of work is enshrined goodness. (Erfanian, 1385)

\section{CONCLUSION}

Evidence has shown that at any time when the pressure has fallen, dictatorship has provided liberal background, as this is accompanied with the interaction of cultures replicated maturity and improved humanist vision, and followed by scientific and technical achievements. As it is shown clearly, wisdom is in Ardavyrafnameh character, and Viraf is a mystic man.

Divina Commedia is a religious text but the presence of Virgil is symbolic; it symbolizes wisdom, intellect and humanism. The main similarity between the two work, is cultural change in East and west, the rise of humanist thinking and rationalism .obviously the act of rethinking originality, humanity and wisdom, provides the field of intellectual independence and the growth of knowledge and science, This bright situation was achieved in the East at the 3rd and $4^{\text {th }}$ centuries, and in the West at sixteen and eighteenth centuries.

\section{REFERENCE LIST}

Alighieri, D. (1968). Divina Commedia (Hell). Tehran: Amir Kabir Publications.

Bracket, O. (2001). History of Theater of the World. Tehran: Mrvaryd Publications.

Bozorgmehr, M. (2010). Sixth Book of Dyngard. PhD thesis. Tehran: Tehran University Publication.

Ershad, F. (2002). A Comparative History in Evolution, Rationalism and Humanism in East and West. Iranian Sociological Magazine. Fifth Edition. p 1:146-157.

Erfanian, F. (2005). The Element of Evil in Ardavirafnameh and Divina Commedia. Art and Architecture Magazine, Winter, Number 86: 56-79.

Hejazi, B. (2010). Molavi Masnavi and Imagination in the Meta Reality. Language and Literature Exploration Magazine. Fall and Winter, Number 23, Scientific Research Magazine: 16-135.

Hynl J. (1995). The Recognition of Iranian Mythology, Amozgar, J. and Tafzili A. (trans.).Tehran: Cheshmeh Publications.

Menui M. (2001). Fifteen Speeches. First Edition. Tehran: Tehran University Publications.

Moen, M. (2004). Gender Name. Tehran: Amir Kabir Publication.

Pourdavod, A. (2006). Gattha. Tehran: Asatir Publications.

Safa, Z. (2008). History of Literature in Iran. Tehran: Foros Publication.

Tafzili, A. (2007). Minooekherad. Fourth Edition. Farnabagh, (2006), Second Edition. Tehran.

Yasami, R. (2005), Ardavyrafnameh. Qom: Human Science Research Center.

Vejdany, F. (2011). "Review in Shahnameh". Scientific Research Magazine. Tehran. Spring, Number 24:4153. 